\title{
AN ANALYSIS OF STUDENTS' DIFFICULTIES IN TRANSLATING DESCRIPTIVE TEXT (A CASE STUDY AT FIRST SEMESTER OF CATHOLIC UNIVERSITY OF SAINT THOMAS MEDAN)
}

\author{
Karisma E. Tarigan* \\ Surel: erick_tarigan2006@yahoo.com
}

\begin{abstract}
The Objective of this study entitled "An Analysis of Students' Difficulties in Translating Descriptive Text (A Case Study at First Semester of Catholic University of Saint Thomas Medan)" was to identify, classify and describe the student's difficulties in translating descriptive text. The subject of this study was twenty two students at the first semester of Catholic University of Saint Thomas Medan. The writer used the test as an instrument. In collecting the data the students translated the descriptive text. The result of this study showed that the students found the difficulties in syntactic ambiguity in sentence and sequence of word meaning 51\% in the form of adjective (95\%), Noun Phrase (86\%).
\end{abstract}

Keywords: Difficulties, Syntactic Ambiguity, Translation.

\section{INTRODUCTION}

In the world of globalization, English is very important as it is used as an international language for a number of purposes ranging from academics, news, business, diplomacy, profession to entertainment. Kitao (2000) confirms that "English is used not only for communication between native speakers and nonnative speakers of English but also between nonnative speakers, and it is the most widely used language in the world, and it will be used by more people in the future.

In Indonesia, English becomes an essential language subject of education issues. Indonesia Government admits English as the first foreign language that is taught to Indonesian students. To be good in using English to communicate or studying, students have to master the four language skills which are reading, writing, listening and speaking.

This fact implies that people all over the world, including Indonesians should master English for diverse purposes. For Indonesians, English is learned mainly for the absorption and development or relation with other nations. The function of English is a medium that students can improve their abilities in science, technology, art and culture so that they will not feel neglected in their society. On the other hand, the goal of study English is to develop culture and profit able science and technology that the developing countries have. We can obtain the information and study it easily so that we are able to translate the information from English into

Indonesian. For this reason, translation skill has to be given to the students in Senior High School where the students obtain English 
course in the class. This is important for the students to take a course and how to understand questions in English as well.

Based on the background of the study above, the following research question is formulated; what are the student's difficulties in translating descriptive text of the first semester of Catholic University of Saint Thomas Medan?

Based on the formulation of the problem above, the objective of this study is to identify, classify and describe the student's difficulties in translating descriptive text of the first semester of Catholic University of Saint Thomas Medan.

The significance of this study is to find the difficulties of students of the first semester Catholic University of Saint Thomas Medan, the finding of this study is to give the benefit for the other learners of students university Saint Thomas Medan. The students will be aware of difficulties that they face in translation subject. Then, they will translate more carefully and evaluate the difficulties. The last, this study

gives contribution for next researchers who want to conduct similar field of research. They can use this study as the additional reference about the translation subject that students faced in translating the text.

According to Brown (2000:216) "mistakes, misjudgments, miscalculations, and error form an important aspect of learning in acquiring information." In line with brown, Richard and Liu (1994) translation or interpretation naturally presents types of difficulties. In the case of simultaneous interpretation, the process consists of three stages: understanding, conversion and delivery. In addition, the difference the three things have to be done almost at the same time. The specific difficulties it offers are;

a. To hear, understand and memorize the words uttered in the source language,

b. To provide an instant supply or required in the target language relying on the built-in stock of equivalents,

c. To express the ideas in the target language while listening to something different in the source language

In addition, Nord (2005:166) difficulties in translation do not only result from the nature of a source text and its situation in relation to all the possibilities of the target language. They also depend on the level of knowledge and competence of translator, on the translation skopos (i.e. the stylistic, functional, and pragmatic qualities required of the target text), as well as on the (technical) working conditions which the translator has to cope with.

As the translator reads through the text he/she should not down any lexical items which seen to be key words, in order to find a good lexical equivalent in the receptor language. Later, when she/he begins transfering into the reception language he must be careful. 
However, that he does not slavishly follow the material and end-up with pseudoconcordance.

If the text is a very long one, the translator will need to decide it into smaller units work on one of these at the time. Therefore, it is important to study the groupings of the text next. If the text devided into sections of chapters, this maybe helpful. But if, as in the case of the Bible, there are chapter devisions marked which do not actually coincide with the grammatical and semantic units of the source text, the translator will need to be very careful os looks for boundaries of units. The goal exegesis is to determine the meaning which is to be communicated in the receptor language text.

Analysis is the separation of a compound subtance, by chemical processes, into constituents, with a view of to as certain either (a) what elements it contains, or (b) how much of each elements is present. It means that in the process of analyzing smething we try to explain it by deviding or breaking it into

parts. It can be clearly understandable. In this study, analysis means the way of the writer analyze the student's translation especially the errors in grammar, content and vocabulary.

Most writers on translation theory agree that before embarking upon any translation the translator should analyze the text comprehensively, since this appears to be only way of ensuring that the source text (ST) has been wholly and correctly understood (Nord 2005). Therefore, Robinson (2007:208) state the importance of analysis is taught:

a. Never assume you understand the source text perfectly.

b. Never assume your understanding of the source text is detailed enough to enable you to translate it adequately.

c. Always analyze for text type, genre, register, rhetorical function, etc.

d. Always analyze the source text's syntax and semantics, making sure you know in detail what it is saying, what it is not saying, and what it is implying.

e. Always analyze the syntactic, semantic, and pragmatic relationship between the source language (especially as it appears in this particular source text) and the target language, so that you know what each language is capable and incapable of doing and saying, and can make all necessary adjustments.

f. Always pay close attention to the translation commission (what you are asked to do, by whom, for whom, and why), and consider the special nature and needs of your target audience; if you aren't given enough information about that audience, ask; if the commissioner doesn't know, use your professional judgment to project an audience.

Translation or interpretation 
Karisma E. Tarigan: An Analysis Of Students'...

naturally presents types of difficulties. In the case of simultaneous interpretation, the process consists of three stages:

understanding, conversion and delivery. In addition, the difference the three things have to be done almost at the same time. richard and liu (1994) the specific difficulties it offers are;

a. to hear, understand and memorize the words uttered in the source language,

b. to provide an instant supply or required in the target language relying on the built-in stock of equivalents,

c. to express the ideas in the target language while listening to something different in the source language

In line with richard and liu, cao (2007:80) "one of the tasks for the translator in such situations is to recognize and appreciate the linguistic uncertainty that may have occurred, intentionally or unintentionally, in the first place in the original text, and then to convey and retain the vagueness or ambiguity in translation"

One of the text types that should be learnt by the students is descriptive text. Descriptive text is used to create vivid image of person, place or thing. It draws all of the sense, not merely the visual.

Wardiman (2008:16 states, "descriptive text is a text that describes the features of someone, something, or a certain places". The purpose of descriptive text is to describe someone's routines or habits. Social function of the descriptive is to describe a particular person, place, or thing.

\section{RESEARCH METHODOLOGY}

In this research the writer used the descriptive qualitative research methodology. Using descriptive qualitative method explains the problem solving. This research is not only sample colleting the data, but covers data analysis, and interpretation to the research problem.

This research was conducted at study Program of English Education Faculty of Teacher Training and Education University of Saint Thomas. In case of the data chosen, it was chosen by lecture's document in translation class.

The object of this study is the 22 students' worksheet of English Education Faculty of Teacher Training and Education of University of Saint Thomas. The subject of this study is the difficulties of translating descriptive text in students' work sheet. The writer used documentation as the instrument of this study. The documentation is the students' worksheet of English Education Faculty of Teacher Training and Education of University of Saint Thomas.

To collect the data, the writer used document analysis as the method of collecting data. Sugiyono (2009) state that documentation is the past event record, it can be in writing, pictures, or works from 
anyone. It is a technique of data collection through written inheritance on archives, the idea of books theory, and proposition related to the research problem. The data is the student's translation tests taken from the lecture's document in translation class.

The main technique used in analyzing the data was descriptive to investigate the difficulties in the

\section{RESEARCH FINDING Difficulties} of Syntactic Ambiguity
English sentences to Indonesian sentences found in the students' worksheet. The last step in analyzing data, the writer also gave some information based on the research which has been done, in order to give many contributions for teacher in teaching or in preparation of teaching translation materials based on the students' work.

Table 1. Analysis of Difficulties

\begin{tabular}{|c|c|c|c|c|c|}
\hline No & $\begin{array}{l}\text { Students } \\
\text { mistakes }\end{array}$ & $\begin{array}{l}\text { Frequency } \\
\text { of error }\end{array}$ & $\begin{array}{l}\text { Percentage } \\
\%\end{array}$ & $\begin{array}{c}\text { Source } \\
\text { language }\end{array}$ & Students translation \\
\hline 1. & 15 & 2 & $68 \%$ & $\begin{array}{l}\text { It is the most } \\
\text { famous } \\
\text { island in } \\
\text { Indonesia }\end{array}$ & $\begin{array}{l}\underline{\text { Itu }} \text { merupakan } \\
\text { pulau yang terkenal } \\
\text { di Indonesia }\end{array}$ \\
\hline 2. & 21 & 5 & $95 \%$ & $\begin{array}{l}\underline{\text { It is an }} \\
\text { awesome } \\
\text { place which } \\
\text { holds } \\
\text { spectacular } \\
\text { combination } \\
\text { of natural } \\
\text { beauty and } \\
\text { cultural } \\
\text { landscape }\end{array}$ & 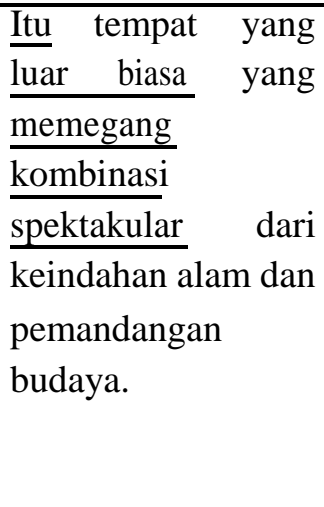 \\
\hline 3. & 19 & 3 & $86 \%$ & $\begin{array}{l}\text { Its beauty } \\
\frac{\text { blends in }}{\text { harmony }} \\
\text { with warm } \\
\text { and friendly } \\
\text { people }\end{array}$ & 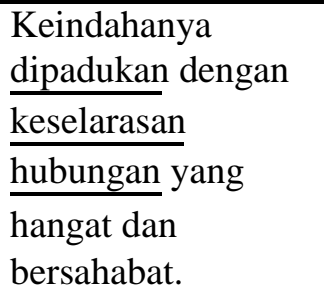 \\
\hline 4. & 16 & 2 & $72 \%$ & $\begin{array}{l}\text { Here the } \\
\text { culture } \\
\text { continues to } \\
\text { be preserved }\end{array}$ & $\begin{array}{llr}\text { Disini budayanya } \\
\text { di lestarikan } & \text { dari } \\
\text { generasi } & \text { ke } \\
\text { generasi } & \end{array}$ \\
\hline
\end{tabular}




\begin{tabular}{|c|c|c|c|c|c|}
\hline & & & & $\begin{array}{l}\text { from } \\
\text { generation to } \\
\text { generation }\end{array}$ & \\
\hline 5. & 15 & 4 & $68 \%$ & $\begin{array}{l}\text { names; the } \\
\text { island of } \\
\text { gods, } \\
\text { B thousand } \\
\text { temples } \\
\text { island, and } \\
\text { the island of } \\
\text { paradiseali is } \\
\text { well known } \\
\text { by many }\end{array}$ & $\begin{array}{l}\text { Bali dikenal dengan } \\
\text { banyak nama; } \\
\text { pulau Tuhan, pulau } \\
\text { beribu } \\
\text { pulau firdaus. }\end{array}$ \\
\hline 6. & 18 & 3 & $81 \%$ & $\begin{array}{l}\text { People } \\
\text { Bali } \\
\text { island the } \\
\text { paradise' of } \\
\text { not without } \\
\text { reason. }\end{array}$ & \begin{tabular}{lr} 
Orang & menamakan \\
\cline { 3 - 3 } buli dengan \\
sebutan & pulau \\
$\frac{\text { firdaus }}{\text { alasan }}$ &
\end{tabular} \\
\hline 7. & 16 & 4 & $72 \%$ & $\begin{array}{l}\text { Bali has } \\
\text { outstanding } \\
\text { natural } \\
\text { beauty like a } \\
\frac{\text { volcano that }}{\text { looks close }} \text { and big; } \\
\text { endless green } \\
\text { paddy fields } \\
\text { which give a } \\
\text { sense of } \\
\text { peace and } \\
\text { tranquility; } \\
\text { as well as the } \\
\text { grains of } \\
\text { Balinese } \\
\text { beach sand } \\
\text { and the } \\
\text { beauty of the } \\
\text { sea and the } \\
\text { beauty of the } \\
\text { sea which are } \\
\text { so } \\
\text { mesmerizing. }\end{array}$ & 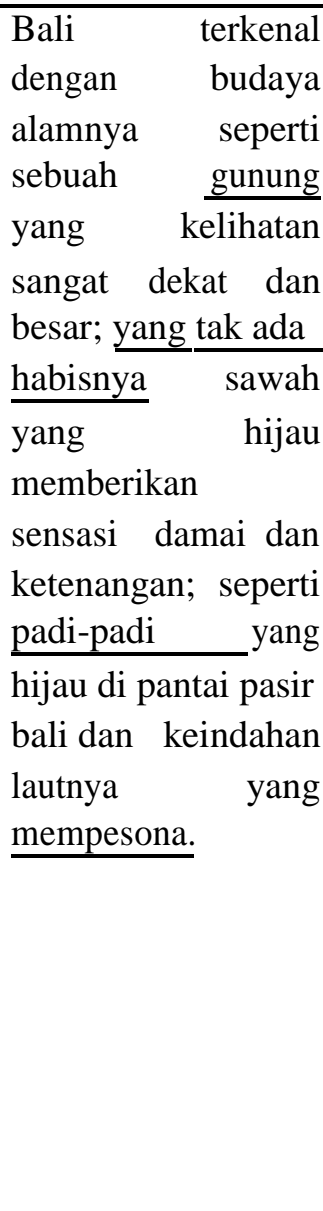 \\
\hline
\end{tabular}


SCHOOL EDUCATION JOURNAL VOLUME 8 NO. 2 JUNI 2018

\begin{tabular}{|c|c|c|c|c|c|}
\hline Total & 136 & 31 & $72 \%$ & $\begin{array}{l}\text { This exotic } \\
\text { island has } \\
\text { many } \\
\text { interesting } \\
\text { things to } \\
\text { offer; } \\
\text { ranging from } \\
\text { spiritual life } \\
\text { and } \\
\text { traditional } \\
\text { culinary to } \\
\text { extraordinary } \\
\text { experience } \\
\text { such surfing, } \\
\frac{\text { diving, and }}{\text { jungle }} \\
\underline{\text { tracking }} \\
\text { which } \\
\text { challenging } \\
\text { your } \\
\text { courage. }\end{array}$ & 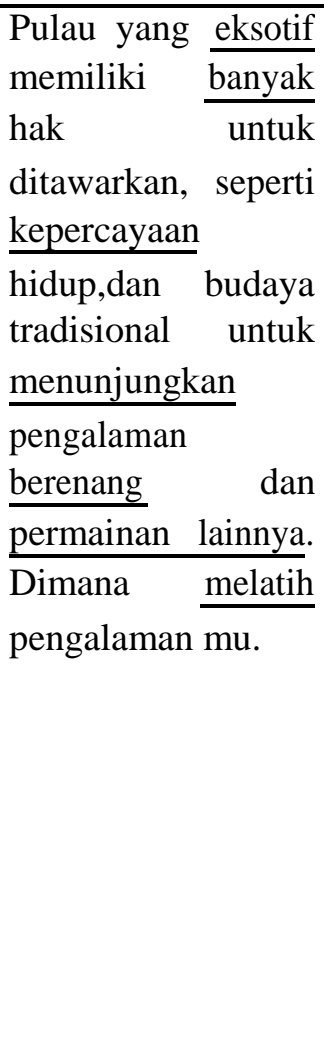 \\
\hline
\end{tabular}

Table 2. Students Mastery Level In Terms Of Difficulties

\begin{tabular}{l|l}
\hline \multicolumn{1}{c|}{ DIFFICULTIES } & \multicolumn{1}{c}{ LEVEL OF MASTERY } \\
\hline $8 \%-15 \%$ & Very Good \\
$16 \%-30 \%$ & Good \\
$31 \%-45 \%$ & Fair \\
$46 \%-50 \%$ & Poor \\
$51 \%-100 \%$ & Very Poor \\
\hline
\end{tabular}

Based on the result, more than $51 \%$ of students make mistakes. It found that in this study the students had difficulty in translation since they still made many errors Thus; it means that the student's level of translation is still poor since they still faced difficulties in certain items of ambiguity translation.

This study, as it has been mentioned in advance, aimed at finishing out weather the students have problems in translation. The data analysis of the test in descriptive text shows that difficulties of syntactic ambiguity are the mistake that often found. The researcher thinks that it happened because most of the students still have problems especially with the use of tense, auxiliaries, vocabulary and special patterns on the syntactic ambiguity in the form of adjective about $95 \%$ and noun phrase about $86 \%$ in sentence. 


\section{CONCLUSION}

After discussing the problem

of difficulties in translating descriptive text found in the students' worksheet, the writer found some factors in translating descriptive text such as the equivalent meaning in syntactic ambiguity from translating English sentences to Indonesian sentences; it can be seen from the percentage of students' mistake about $51 \%$ in syntactic ambiguity.

Based on the conclusion above this study shows that various ways in translating are provided to the translator to achieve accurateness, the equivalence, and made the translation is acceptable. Translators should face some problems in translating two different languages because the differences of ambiguity meaning in grammatical categories of the two languages. Regarding to this point, a translator should have capability in translating and interpreting the meaning in a single sentence or sequence of words

\section{REFERENCES}

Brown, Douglas. H. 2000. Teaching by principles: Interactive Approach to Language. San Fransisco: Addison Wesley Longman.

Christiane nord. 2005. Text analysis in translation; theory, methodology, and Didactic Application of a Model for

Translation-Oriented Text Analysis. Second addition. NewYork.
Debora cao. 2007. Translating Law: Topic in Translation, British library.

Kitao, K. 2000. Teaching Culture in Foreign Language. Instruction in the Unites States.

Nord Chirstine. 2005. Text analysis in Translation: Theory, Methodology, and Didactic Application of a model for Translation-oriented Text Analysis. Second Edition. New York.

Richard K. Seymour and Jingzhi Liu. 1994. Translation and Interpreting: Bridging East and West: Volume 8 . University of Hawaii Press.

Robinson H. Douglas. 2007. Translation and The problem of Sway. John Benjamins Publishing Company.

Sugiyono, 2009. Metode Penelitian Kuantitatif Kualitatif dan $R \& D$. Bandung: Penerbit Alfabeta.

Wardiman, Artono. 2008. English in Focus for Grade Vii Junior High School. Bandung: Departemen Pendidikan Nasional. 